\title{
Response of leaf, non-leaf yield characters and plant fraction interrelationship of indigenous wild cucumber Cucumis myriocarpus to varying irrigation intervals and NPK fertilizer rates
}

\author{
R. J. Nkgapele, M. S. Mphosi \& K. G. Shadung \\ Limpopo Agro-food Technology station, School of Agriculture and \\ Environmental Sciences, University of Limpopo, Republic of South Africa
}

\begin{abstract}
Wild-cucumber, Cucumis myriocarpus, is among the most important indigenous crop plants in rural Limpopo Province of South Africa, primarily used as an ethno-botanical crop and a leafy green vegetable. An experiment laid out in a split-plot design and replicated three times was conducted to study the effects of irrigation frequency (2, 4 and 6 day interval) and NPK fertilizer rate (0 Kg NPK ha ${ }^{-1}, 60-40-20 \mathrm{~kg}$ NPK ha- ${ }^{-1}, 120-80-40 \mathrm{~kg} \mathrm{NPK} \mathrm{ha}^{-1}$ and 180-120-60 kg NPK ha ${ }^{-1}$ ) on leaf and non-leaf yield characters and plant fraction interrelationships of Cucumis myriocarpus. The intermediate treatment of four day irrigation interval and $120-80-40 \mathrm{~kg}$ NPK ha ${ }^{-1}$ application rate produced significantly higher $(\mathrm{P}<0.05)$ leaf and non-leaf yield characters than the extreme treatments of short two day irrigation intervals and low 60-40-20 kg NPK ha ${ }^{-1}$; and long six day irrigation intervals and 180-120-60 $\mathrm{kg} \mathrm{NPK} \mathrm{ha}^{-1}$. Only fresh plant fraction interrelationships were significant. In conclusion, the results of the study indicate that Cucumis myriocarpus can be successfully grown using conventional production methods and supply rural households with good yields of a leafy green vegetable as well as providing raw materials needed for ethnobotanical purposes.
\end{abstract}

Keywords: yield characters, wild cucumber, ethno-medicine, leaf area. 


\section{Introduction}

Since time immemorial useful plants have been handled by human societies for food and medicinal purposes. Cucumis myriocarpus is a traditional leafy vegetable and ethno-medicinal plant of which the leafy parts are used as a vegetable while the remaining parts stems and roots are used in ethno-medicine, thereby utilizing the whole plant. There are many different species of leafy vegetables used in South Africa, many of which are fairly localized [1]. Traditional crop plants are an important source of nutrients and vitamins for the rural population, as many nutritional studies have shown [2,3]. Farmers have cultivated and collected these vegetables for generations as an additional food source. Many of these species are not readily amenable to conventional agronomic studies as often they are grown in small patches in home gardens. The leafy vegetables of African tradition are being displaced in many areas, leading to a decline in production, use, and diversity of vegetables being grown [4]. Natural selection and farmer-based breeding practices have developed the genetic base of the most important vegetables, but the lack of attention by research and development is leading to the under-exploitation of these vegetables [5]. The scenario thus far described encourages continuing genetic erosion, and further restricting the development options for the rural poor. This trend will clearly have a detrimental impact on the nutritional status of households, and the incomes of women farmers, in particular, who constitute the primary producers, consumers, and sellers of these vegetables [6]. Crucially, from a national and cultural standpoint, these vegetables constitute a most valuable natural resource that needs to be preserved. In recent decades there has been formal research by national agricultural research programmes and international research organizations on cultivation methods of traditional vegetables to improve their yield.

The ratios of roots to shoots are important in that they give a clear indication of biomass partitioning in crop plants. Plants that encounter limited nutrients or water supply are expected to partition more biomass to their roots and less to their stems and leaves. Accordingly, in limiting light environments, plants are expected to partition more new biomass to stem and leaf production and less to root production [7]. This is attributed to the relations that roots are dependent on shoots for carbohydrates, growth regulators, and some other organic compounds, and severe reduction in canopy area by pruning, insect defoliation, grazing, or diversion of food into fruit and seed production is likely to reduce the root growth [8]. In a similar pattern, damage to root system will reduce water and mineral absorption, which in turn inhibits shoot growth. Shoots are dependent on roots for growth regulators such as abscisic acid, cytokinins and gibberellins [9].

The objective of the current study was to quantify and analyse the effects of varying irrigation interval and NPK application rates on leaf and non-leaf yield characters and plant fraction interrelationships of wild traditional leafy crop Cucumis africanus under greenhouse growing condition. 


\section{Materials and methods}

A greenhouse experiment was conducted at Horticultural Research Facility of University of Limpopo, Limpopo Province, South Africa (23 ${ }^{\circ} 53^{\prime} 10^{\prime \prime}$ S; $29^{\circ} 44^{\prime} 15^{\prime \prime}$ E) during the 2009-2010 summer growing season. Ambient day/night temperatures averaged $28 / 21^{\circ} \mathrm{C}$, with maximum temperatures controlled using thermostatically-activated fans.

The experiment was laid out in a split-plot design arrangement and replicated three times. Three irrigation intervals, namely, 2, 4 and 6 days, were accorded as main plots. During each irrigation interval, $1000 \mathrm{ml}$ tap-water was applied per pot. Irrigation water application treatments were applied seven days after transplanting. NPK application rates of $0 \mathrm{Kg} \mathrm{NPK} \mathrm{ha}^{-1}, 60-40-20 \mathrm{~kg} \mathrm{NPK} \mathrm{ha}{ }^{-1}$, 120-80-40 kg NPK ha ${ }^{-1}$ and 180-120-60 kg NPK ha ${ }^{-1}$ were accorded to sub-plot treatments.

Seedlings were raised in seedling trays using thirty-cm-diameter plastic pots, filled with $10 \mathrm{~L}$ steam-pasteurised sand and Hygromix $(3: 1 \mathrm{v} / \mathrm{v})$, which were placed on greenhouse benches at $0.5 \mathrm{~m}$ inter-row and $0.6 \mathrm{~m}$ intra-row spacing. Uniform three-week-old Cucumis myriocarpus seedlings were transplanted to the pots one day after irrigating the growing medium to field capacity. NPK fertilizer $(3: 2: 1)$ was given in split doses. First dose was applied at transplanting of seedlings into $30 \mathrm{~cm}$ plastic pots, while the remaining dose was applied 20 days after the first dose.

At 40 days after transplanting (40 DAT) plants were harvested. Above- and below-ground plant parts were separated into roots, stems and leaves. Sample pots were emptied and roots carefully separated from the soil mixture using a gentle stream of water. Canopy area was measured using canopy area meter (LI3100C, LI-COR, Bioscience, Lincoln, NE 68504 USA) and then fresh and dry root, stem and leaf weights were determined using a standard balance scale. The collected data was recorded for the following leaf yield characters: leaf biomass, shoot biomass, leaf length, Leaf width and canopy area; non-leaf yield characters: root biomass, stem biomass, main vine length, lateral vine length, lateral vine number and root length; and ratios of plant fractions: root/stem, root/leaf, root/shoot and leaf/stem.

The data of all the above mentioned parameters were individually subjected to the analysis of variance techniques using Statistix 8.1 software (Statistix, Analytical Software, Statistix; Tallahassee, FL, USA, 1985-2003). Mean comparisons were done using least significance difference (LSD) at 0.05 level of probability $[10,11]$. When treatments were significant sum of squares were partitioned to determine the percentage contribution of source of variation to the total treatment variation [12]. 


\section{Results}

\subsection{Yield characters}

\subsubsection{Leaf yield characters}

Leaf yield characters were influenced $(\mathrm{P}<0.05)$ by the interaction between irrigation frequency and NPK fertilizer application rate with the highest characters of leaf area, leaf width and leaf length being correspondingly 136, 17.5 and $59.6 \%$ higher than lowest characters (Table 1). The interaction was responsible for $15.2,18.7$ and $10.1 \%$ of variation in treatments. Only leaf width was influenced by irrigation water application which contributed $10.4 \%$ total treatment variations (Table 2).

Table 1: Leaf yield characters of Cucumis myriocarpus as affected by irrigation interval and NPK application rate at 40 DAT during the 2009/10 growing season.

\begin{tabular}{|c|c|c|c|c|}
\hline $\begin{array}{c}\text { Irrigation } \\
\text { interval }\end{array}$ & NPK rate & $\begin{array}{l}\text { Leaf } \\
\text { area }\end{array}$ & $\begin{array}{l}\text { Leaf } \\
\text { width }\end{array}$ & $\begin{array}{l}\text { Leaf } \\
\text { length }\end{array}$ \\
\hline days & $\mathrm{kg} \mathrm{ha}^{-1}$ & $\mathrm{~mm}^{2}$ & \multicolumn{2}{|c|}{---------mm-------- } \\
\hline \multirow[t]{4}{*}{2} & 0 & $128.0 \mathrm{bc}$ & $13.73 \mathrm{ab}$ & $44.6 \mathrm{ab}$ \\
\hline & 60 & $123.1 \mathrm{bc}$ & $14.03 \mathrm{a}$ & $40.9 \mathrm{ab}$ \\
\hline & 120 & $141.9 \mathrm{ab}$ & $14.13 \mathrm{a}$ & $44.4 \mathrm{ab}$ \\
\hline & 180 & $75.52 \mathrm{bcd}$ & $13.07 \mathrm{ab}$ & $35.6 \mathrm{~b}$ \\
\hline \multirow[t]{4}{*}{4} & 0 & $67.82 d$ & $12.17 \mathrm{~b}$ & $43.3 \mathrm{ab}$ \\
\hline & 60 & $136.7 \mathrm{ab}$ & $13.47 \mathrm{ab}$ & $49.8 \mathrm{ab}$ \\
\hline & 120 & $159.9 \mathrm{a}$ & $13.37 \mathrm{ab}$ & $56.8 \mathrm{a}$ \\
\hline & 180 & $114.1 \mathrm{bc}$ & $13.47 \mathrm{ab}$ & $43.2 \mathrm{ab}$ \\
\hline \multirow[t]{4}{*}{6} & 0 & $137.9 \mathrm{ab}$ & $13.83 \mathrm{a}$ & $45.7 \mathrm{ab}$ \\
\hline & 60 & $134.9 \mathrm{ab}$ & $13.80 \mathrm{a}$ & $44.5 \mathrm{ab}$ \\
\hline & 120 & $121.1 \mathrm{bc}$ & $13.23 \mathrm{ab}$ & $44.1 \mathrm{ab}$ \\
\hline & 180 & $156.0 \mathrm{ab}$ & $14.30 \mathrm{a}$ & $45.5 \mathrm{ab}$ \\
\hline
\end{tabular}

Column means with the same letter were not different at $5 \%$ level according to the least significant difference test; $\mathrm{ns}=$ non-significant; $60=60-40-20$, $120=120-80-40,180=180-120-60$.

\subsubsection{Non-leaf yield characters}

Significant $(\mathrm{P}<0.05)$ differences were demonstrated in non-leaf yield characters in response to irrigation frequency and NPK fertilizer application rate, except number of lateral vines per plant which was non-significant (Tables 3 and 4). NPK application rate accounted for 31,26 and $23 \%$ of the total variation for main vine, lateral and root lengths, respectively (Table 3). The longest non-leaf yield characters of main vine, lateral vine and root length were 149, 242 and 56\% longer than shortest characters, respectively (Table 4). 
Table 2: Analysis of variance for leaf yield characters of Cucumis myriocarpus as affected by irrigation interval and NPK application rate at 40 DAT during the 2009/10 summer growing season.

\begin{tabular}{|l|l|l|l|l|l|l|l|}
\hline \multirow{2}{*}{$\begin{array}{l}\text { Source of } \\
\text { variation }\end{array}$} & \multirow{2}{*}{ Df } & \multicolumn{6}{|c|}{ Yield characters } \\
\cline { 3 - 8 } & & \multicolumn{2}{|c|}{ Leaf area } & \multicolumn{2}{c|}{ Leaf width } & \multicolumn{2}{c|}{ Leaf length } \\
\cline { 3 - 8 } & $\mathbf{S S}$ & $\mathbf{6}$ & $\mathbf{S S}$ & $\mathbf{\%}$ & $\mathbf{S S}$ & $\%$ \\
\hline $\begin{array}{l}\text { Replicate } \\
(\mathrm{A})\end{array}$ & 2 & 26019 & 3.73 & 1.252 & 3.83 & 187.53 & 5.96 \\
\hline $\begin{array}{l}\text { Irrigation } \\
(\mathrm{B})\end{array}$ & 2 & 30492 & $4.37 \mathrm{~ns}$ & 3.395 & $10.4 * *$ & 287.87 & $9.14 \mathrm{~ns}$ \\
\hline Error $\left(\mathrm{A}^{*} \mathrm{~B}\right)$ & 4 & 31297 & 4.49 & 0.748 & 2.29 & 100.96 & 3.21 \\
\hline $\begin{array}{l}\text { NPK rate } \\
(\mathrm{C})\end{array}$ & 3 & 45789 & $6.57 \mathrm{~ns}$ & 1.303 & $3.98 \mathrm{~ns}$ & 221.90 & $7.05 \mathrm{~ns}$ \\
\hline $\mathrm{B} * \mathrm{C}$ & 6 & 106169 & $15.2 * *$ & 6.125 & $18.7 * *$ & 317.56 & $10.1 * *$ \\
\hline $\begin{array}{l}\text { Error } \\
(\mathrm{A} * \mathrm{~B} * \mathrm{C})\end{array}$ & 18 & 457397 & 65.6 & 19.89 & 60.8 & 2031.1 & 64.5 \\
\hline Total & 35 & 697162 & 100 & 32.71 & 100 & 3146.9 & 100 \\
\hline
\end{tabular}

*** Significant $(\mathrm{P}<0.01)$, ** Significant $(\mathrm{P}<0.05), \mathrm{Df}=$ degree of freedom, $\mathrm{SS}=$ sum of squares, ns $=$ non-significant.

Table 3: Analysis of variance for non-leaf yield characters of Cucumis myriocarpus as affected by irrigation interval and NPK application rate at 40 DAT during the 2009/10 growing season.

\begin{tabular}{|l|l|l|c|c|c|c|c|c|c|}
\hline \multirow{2}{*}{$\begin{array}{l}\text { Source of } \\
\text { variation }\end{array}$} & \multirow{2}{*}{ Df } & \multicolumn{7}{|c|}{ Yield characters } \\
\cline { 2 - 10 } & & \multicolumn{2}{|c|}{ Main vine } & \multicolumn{2}{c|}{ Lateral vine } & \multicolumn{2}{c|}{ Root length } & \multicolumn{2}{|c|}{$\begin{array}{l}\text { Lateral } \\
\text { vine no. }\end{array}$} \\
\cline { 2 - 10 } & SS & \multicolumn{1}{c}{$\%$} & SS & $\%$ & SS & $\%$ & SS & $\%$ \\
\hline $\begin{array}{l}\text { Replicate } \\
(\mathrm{A})\end{array}$ & 2 & 786 & 2.5 & 79 & 0.81 & 0.39 & 0.02 & 0.166 & 1.13 \\
\hline $\begin{array}{l}\text { Irrigation } \\
(\mathrm{B})\end{array}$ & 2 & 3816 & $12.3 \mathrm{~ns}$ & 50 & $0.52 \mathrm{~ns}$ & 49.4 & $2.3 \mathrm{~ns}$ & 0.001 & $0.01 \mathrm{~ns}$ \\
\hline $\begin{array}{l}\text { Error } \\
(\mathrm{A} * \mathrm{~B})\end{array}$ & 4 & 2938 & 9.5 & 805 & 8.27 & 406 & 18.6 & 1.333 & 9.04 \\
\hline $\begin{array}{l}\text { NPK rate } \\
(\mathrm{C})\end{array}$ & 3 & 9581 & $31 * * *$ & 2537 & $26.1 * *$ & 506 & $23 * *$ & 0.972 & $6.59 \mathrm{~ns}$ \\
\hline $\mathrm{B} * \mathrm{C}$ & 6 & 4429 & $14.3 \mathrm{~ns}$ & 1823 & $18.7 \mathrm{~ns}$ & 109 & $5.0 \mathrm{~ns}$ & 1.111 & $7.53 \mathrm{~ns}$ \\
\hline $\begin{array}{l}\text { Error } \\
(\mathrm{A} * \mathrm{~B} * \mathrm{C})\end{array}$ & 18 & 9369 & 30.3 & 4434 & 45.6 & 1106 & 50.8 & 11.17 & 75.7 \\
\hline Total & 35 & $\begin{array}{l}3091 \\
9\end{array}$ & 100 & 9727 & 100 & 2178 & 100 & 14.75 & 100 \\
\hline
\end{tabular}

$* * *$ Significant $(\mathrm{P}<0.01)$, ** Significant $(\mathrm{P}<0.05), \mathrm{Df}=$ degree of freedom, $\mathrm{SS}=$ sum of squares, ns $=$ non-significant. 
Table 4: Non-leaf yield characters of Cucumis myriocarpus as affected by irrigation interval and NPK application rate at 40 DAT during the 2009/10 growing season.

\begin{tabular}{|c|c|l|l|l|l|}
\hline $\begin{array}{c}\text { Irrigation } \\
\text { Interval }\end{array}$ & $\begin{array}{c}\text { NPK } \\
\text { rate }\end{array}$ & $\begin{array}{c}\text { Main } \\
\text { vine }\end{array}$ & $\begin{array}{c}\text { Lateral } \\
\text { vine }\end{array}$ & $\begin{array}{c}\text { Root } \\
\text { length }\end{array}$ & $\begin{array}{c}\text { No. of } \\
\text { vines }\end{array}$ \\
\hline days & $\mathrm{kg} \mathrm{ha}^{-1}$ & $------------c m-----------$ & \\
\hline 2 & 0 & $51.3 \mathrm{bc}$ & $26.0 \mathrm{bc}$ & $46.7 \mathrm{a}$ & 1.7 \\
\hline & 60 & $88.7 \mathrm{abc}$ & $33.3 \mathrm{bc}$ & $30.0 \mathrm{~b}$ & 1.6 \\
\hline & 120 & $83.7 \mathrm{abc}$ & $33.0 \mathrm{bc}$ & $36.3 \mathrm{ab}$ & 2.0 \\
\hline & 180 & $109.3 \mathrm{a}$ & $65.0 \mathrm{a}$ & $37.7 \mathrm{ab}$ & 1.7 \\
\hline 4 & 0 & $45.0 \mathrm{c}$ & $19.0 \mathrm{c}$ & $44.0 \mathrm{ab}$ & 1.3 \\
\hline & 60 & $112.7 \mathrm{a}$ & $34.3 \mathrm{bc}$ & $38.3 \mathrm{ab}$ & 1.6 \\
\hline & 120 & $96.3 \mathrm{ab}$ & $47.1 \mathrm{ab}$ & $40.0 \mathrm{ab}$ & 2.0 \\
\hline & 180 & $91.7 \mathrm{ab}$ & $47.0 \mathrm{ab}$ & $39.0 \mathrm{ab}$ & 2.2 \\
\hline 6 & 0 & $56.3 \mathrm{bc}$ & $34.0 \mathrm{bc}$ & $45.0 \mathrm{ab}$ & 2.0 \\
\hline & 60 & $80.7 \mathrm{abc}$ & $38.3 \mathrm{abc}$ & $36.3 \mathrm{ab}$ & 1.3 \\
\hline & 120 & $57.0 \mathrm{bc}$ & $38.7 \mathrm{abc}$ & $37.7 \mathrm{ab}$ & 2.0 \\
\hline & 180 & $58.7 \mathrm{bc}$ & $37.0 \mathrm{abc}$ & $40.7 \mathrm{ab}$ & 1.6 \\
\hline & & & & & $\mathrm{ns}$ \\
\hline
\end{tabular}

Column means with the same letter were not different at $5 \%$ level according to the least significant difference test; $\mathrm{ns}=$ none significant; $60=60-40-20$, $120=120-80-40,180=180-120-60$.

Table 5: $\quad$ Fresh plant fraction interrelationships of Cucumis myriocarpus as affected by irrigation interval and NPK application rate at 40 DAT during the 2009/10 growing season.

\begin{tabular}{|c|c|l|l|l|l|}
\hline & & \multicolumn{4}{|c|}{ Ratio of plant fractions } \\
\cline { 3 - 6 } $\begin{array}{l}\text { Interval } \\
\text { (days) }\end{array}$ & $\begin{array}{c}\text { NPK rate } \\
\left(\mathrm{kg} \mathrm{ha}^{-1}\right)\end{array}$ & $\begin{array}{l}\text { Root/ } \\
\text { shoot }\end{array}$ & $\begin{array}{l}\text { Root/ } \\
\text { stem }\end{array}$ & $\begin{array}{l}\text { Root/ } \\
\text { leaf }\end{array}$ & $\begin{array}{l}\text { Leaf/ } \\
\text { stem }\end{array}$ \\
\hline 2 & 0 & $0.17 \mathrm{bc}$ & $0.36 \mathrm{~b}$ & $0.33 \mathrm{~b}$ & 0.53 \\
\hline & 60 & $0.15 \mathrm{c}$ & $0.29 \mathrm{~b}$ & $0.32 \mathrm{~b}$ & 0.46 \\
\hline & 120 & $0.16 \mathrm{bc}$ & $0.32 \mathrm{~b}$ & $0.32 \mathrm{~b}$ & 0.49 \\
\hline & 180 & $0.12 \mathrm{c}$ & $0.24 \mathrm{~b}$ & $0.26 \mathrm{~b}$ & 0.48 \\
\hline 4 & 0 & $0.47 \mathrm{a}$ & $1.12 \mathrm{a}$ & $0.84 \mathrm{a}$ & 0.55 \\
\hline & 60 & $0.17 \mathrm{bc}$ & $0.35 \mathrm{~b}$ & $0.32 \mathrm{~b}$ & 0.56 \\
\hline & 120 & $0.16 \mathrm{bc}$ & $0.37 \mathrm{~b}$ & $0.30 \mathrm{~b}$ & 0.56 \\
\hline & 180 & $0.28 \mathrm{~b}$ & $0.44 \mathrm{~b}$ & $1.04 \mathrm{a}$ & 0.40 \\
\hline 6 & 0 & $0.15 \mathrm{c}$ & $0.31 \mathrm{~b}$ & $0.29 \mathrm{~b}$ & 0.53 \\
\hline & 60 & $0.13 \mathrm{c}$ & $0.29 \mathrm{~b}$ & $0.25 \mathrm{~b}$ & 0.54 \\
\hline & 120 & $0.15 \mathrm{c}$ & $0.36 \mathrm{~b}$ & $0.27 \mathrm{~b}$ & 0.56 \\
\hline & 180 & $0.19 \mathrm{bc}$ & $0.41 \mathrm{~b}$ & $0.36 \mathrm{~b}$ & 0.54 \\
\hline & & & \multicolumn{3}{|c}{} \\
\hline
\end{tabular}

Column means with the same letter were not different at $5 \%$ level according to the least significant difference test; ns = non-significant; $60=60-40-20,120=120-80-40,180=180-120-60$. 


\subsection{Plant fraction interrelationships}

Highly significant differences $(\mathrm{P}<0.01)$ were observed on fresh root/shoot, root/stem and root/leaf ratios while fresh leaf/stem ratio and all dry fraction ratios showed no significant variances; and the highest fresh root/shoot, root/stem and root/leaf ratios were respectively 292,367 and $316 \%$ higher than the least ratios (Table 5). Fresh root/shoot, root/stem and root/leaf ratios responded positively to irrigation frequency, NPK fertilizer application rate and their interaction. Irrigation, NPK application rate and irrigation by NPK interaction accounted for respectively $25.6,21.7$ and $24.2 \% ; 17.2,19.9$ and $12.6 \%$; and $29.9,35.6$ and $23 \%$ of total treatment variation of fresh root/shoot, root/stem and root/leaf ratios (Table 6).

Table 6: Analysis of variance for fresh plant fraction interrelationship of Cucumis myriocarpus as affected by irrigation interval and NPK application rate at 40 DAT during the 2009/10 summer growing season.

\begin{tabular}{|c|c|c|c|c|c|c|c|c|c|}
\hline \multirow{3}{*}{$\begin{array}{l}\text { Source of } \\
\text { variation }\end{array}$} & \multirow{3}{*}{ Df } & \multicolumn{8}{|c|}{ Yield characters } \\
\hline & & \multicolumn{2}{|c|}{ Root/shoot } & \multicolumn{2}{|c|}{ Root/stem } & \multicolumn{2}{|c|}{ Root/leaf } & \multicolumn{2}{|c|}{ Leaf/stem } \\
\hline & & SS & \begin{tabular}{|l}
$\%$ \\
\end{tabular} & SS & $\%$ & SS & $\%$ & SS & $\%$ \\
\hline $\begin{array}{l}\text { Replicate } \\
\text { (A) }\end{array}$ & 2 & 0.014 & 3.35 & 0.02 & 0.94 & 0.22 & 6.18 & 0.03 & 10.3 \\
\hline $\begin{array}{l}\text { Irrigation } \\
\text { (B) }\end{array}$ & 2 & 0.107 & $25.6^{* * *}$ & 0.48 & $21.7 * * *$ & 0.86 & $24.2^{* * *}$ & 0.01 & $3.45 \mathrm{~ns}$ \\
\hline $\begin{array}{l}\text { Error } \\
(\mathrm{A} * \mathrm{~B})\end{array}$ & 4 & 0.012 & 2.87 & 0.04 & 1.96 & 0.29 & 8.15 & 0.09 & 31.0 \\
\hline \begin{tabular}{ll|} 
NPK & rate \\
$(\mathrm{C})$
\end{tabular} & 3 & 0.072 & $17.2 * *$ & 0.44 & $19.9 * * *$ & 0.45 & $12.6^{* *}$ & 0.02 & $6.89 \mathrm{~ns}$ \\
\hline $\mathrm{B}^{*} \mathrm{C}$ & 6 & 0.125 & $29.9^{* * *}$ & 0.78 & $35.6^{* * *}$ & 0.82 & $23.0 * *$ & 0.04 & $13.8 \mathrm{~ns}$ \\
\hline $\begin{array}{l}\text { Error } \\
\left(\mathrm{A} \mathrm{B}^{*} \mathrm{C}\right)\end{array}$ & 18 & 0.088 & 21.1 & 0.44 & 19.9 & 0.91 & 25.6 & 0.09 & 31.0 \\
\hline Total & 35 & 0.418 & 100 & 2.21 & 100 & 3.56 & 100 & 0.29 & 100 \\
\hline
\end{tabular}

*** Significant $(\mathrm{P}<0.01)$, ** Significant $(\mathrm{P}<0.05), \mathrm{Df}=$ degree of freedom, $\mathrm{SS}=$ sum of squares, ns=non-significant

\section{Discussion}

The main food security and health challenge in Limpopo Province, South Africa, is to increase the ability of historically disadvantaged groups to meet their minimum daily requirements for proper nutritious food and medicines. Thus, the benefits of wild resources that provide for food and ethno-medicines to inaccessible rural villages in Limpopo Province of South Africa cannot be ignored. The results of the current study shows that Cucumis myriocarpus, a widely used leafy vegetable and ethno-medicinal crop plant in rural Limpopo Province, can provide significant amounts of leaf and non-leaf plant fraction with multi-purpose benefits.

The intermediate treatment of four day irrigation interval and $120-80-40 \mathrm{~kg}$ NPK ha ${ }^{-1}$ application rate produced significantly higher $(\mathrm{P}<0.05)$ leaf characters 
of canopy area and leaf length than the other extreme treatments of very frequent and infrequent irrigation and low and high NPK application rate, except the leaf width character which was more broader in the frequent two day irrigation interval and low 60-40-20 kg NPK ha ${ }^{-1}$ application rate treatment. This was shown by leaf morphological characters of larger canopy area, larger canopy area and longer leaf length, which are good required for photosynthetic assimilates production and nutrient absorption; thereby yielding of good quality crop.

Other workers confirmed that water and nutrient application promote yield in various vegetables [13] in cucumber, [14] in Amaranthus tricolor L., and [15] in Chinese cabbage (Brassica rapa L. subsp. chinensis). The positive effects interaction between irrigation and NPK application on leaf yield characters indicate their concurrent relevance to production of wild cucumber, $C$. myriocarpus, which can play pivotal role in agricultural development programmes aimed at sustainable rural livelihoods promotion and empowerment. Similarly, non-leaf yield of main vine length was higher in the intermediate irrigation frequency and low NPK input treatment combination.

Lengths of lateral vines were highly pronounced in the treatment combination of frequent irrigation and high NPK application rate, while root lengths were longer in frequent irrigation and low NPK application rate treatment. These results of low leaf and high non-leaf characters in this category can be attributed to the fact that much of the irrigation water and NPK resources were made unavailable to the plant through deep percolation and leaching and the plants responded by strengthening the supporting structures of anchorage. This response is not a negative result since the non-leafy components of the plant are used for ethno-medicinal purposes. Thus, depending on the grower's field of interest either for consumption of the crop as leafy vegetable and/or use for ethno-medicinal purposes the right agronomic cultural practice of irrigation and nutrient application need to be taken into account.

Plant fraction interrelationships in the study showed highly $(\mathrm{P}<0.01)$ distinct variances with four day irrigation interval giving the highest root/shoot and root/stem ratios at $0 \mathrm{~kg} \mathrm{NPK} \mathrm{ha}{ }^{-1}$ application rate and root/leaf ratio at 180-120$60 \mathrm{~kg}$ NPK ha ${ }^{-1}$ application rate, an indication that in this treatment more assimilates where partitioned to the roots [16-18]. The lowest root/shoot, root/stem and root/leaf ratios were given by irrigating on a two and six day irrigation frequency across all levels of NPK application which is an indication that assimilates were distributed to above-ground portions as opposed to below ones.

\section{Conclusions}

The study showed significant influences that varying irrigation water application frequencies and different levels of NPK fertilizer application has on leaf and non-leaf yield characters and the interrelationships of plant fractions. The results also show that wild cucumber, Cucumis myriocarpus, can be successfully grown using conventional agricultural production methods of irrigation and fertilizer application. Thus, supplying rural smallholder systems with good plant fraction 
yields for use as leafy green vegetables as well as providing raw materials needed for ethno-medicinal purposes.

\section{References}

[1] Jansen van Rensburg, W.S., van Averbeke, W., Slabbert, R., Faber, M., van Jaarsveld, P., van Heerden, I., Wenhold, F., and Oelofse, A. African leafy vegetables in South Africa. Water SA, 33 (3), 317-326, 2007.

[2] Flyman, M.V. and Afolayan, A.J. The suitability of wild vegetables for alleviating human dietary deficiencies. Botany, (72), pp. 492-497, 2006.

[3] Faber, M., Oelofse, A., van Jaarsveld, P.J., Wenhold F.A.M., and Jansen van Rensburg, W.S. African leafy vegetables consumed by households in the Limpopo and KwaZulu-Natal. South African Journal of Clinical Nutrition, 23(1), pp. 30-38, 2010.

[4] Seeiso, T.M. and Materechera, S.A. Effects of seed sowing depth on emergence and early seedling development of two African indigenous leafy vegetables. Life Science Journal, 8(2), pp. 12-17, 2011.

[5] Misra, S., Maikhuri, R.K., Kala, C.P., Rao, K.S. and Saxen, K.G. Wild leafy vegetables: A study of their subsistence dietetic support to the inhabitants of Nanda Devi Biosphere Reserve, India. Journal of Ethnobiology and Ethnomedicine, (8), pp. 4-15, 2008.

[6] Smith, I.F. and Eyzaguirre P. African leafy vegetables: their role in the world health organization's global fruit and vegetables initiative. African Journal Food, Agriculture and Nutrition Development, 7 (3), pp. 1-17, 2007.

[7] Reynolds, H. L. and D'Antonio, C. The ecological significance of plasticity in root weight ratio in response to nitrogen: opinion. Journal of Plant \& Soil, 185, pp. 75-97, 1996.

[8] Hopkins, W.G. Introduction to Plant Physiology. John Wiley \& sons, Inc.: New York, pp. 176-189, 1992.

[9] Kramer, P.J. and Boyer, J.S. Water Relations of Plants. Academic Press: London, pp. 158-184, 1995.

[10] Gomez KA, Gomez AA (1984). Statistical procedures for agricultural research $2^{\text {nd }}$ ed. John Wiley \& Sons, New York., pp. 146-184, 1984.

[11] Kuehl R.O. Design of experiments: statistical principles of research design and analysis $2^{\text {nd }}$ ed. Duxbury press, New York., pp. 173-184, 2000.

[12] Little, T.M. and Hills, F.J. Statistical methods in agricultural research, University of California, California, USA, pp. 350, 1981.

[13] Jilani, M.S., Bakar, A., Waseem, K., Kiran, M. Effect of different levels of NPK on the growth and yield of cucumber (Cucumis sativus) under the plastic tunnel. Journal of Agricultural \& Social Science, 5 (3), pp. 99-101, 2009.

[14] Singh, S., Kumari, R., Agrawal, M. and Agrawal, S.B. Modification of growth and yield responses of Amaranthus tricolor L. to sUV-B under varying mineral nutrient supply. Scientia Horticulturae, 120, pp. 173-180, 2009. 
[15] Okorogbona, A.O.M., Van Averbeke, W., Ramusandiwa, T.D. Growth and yield response of Chinese cabbage (Brassica rapa L. subsp. chinensis) as affected by nutrient availability in air-dried and pulverized different types of animal manure using low biological activity soil. World Journal of Agricultural Science, 7 (1), pp. 1-12, 2011.

[16] Gardner, F.P., Pearce, R.B. and Mitchell, R.L. Physiology of crop plants. Iowa state university press: Ames, pp. 187-209, 1985.

[17] Hopkins W.G. Introduction to Plant Physiology. John Wiley \& sons, Inc.: New York, pp. 176-189, 1992.

[18] Prusinkiewicz, P. Modeling plant growth and development. Current Opinion in Plant Biology, 7 (1), pp. 79-83, 2004. 